\title{
DISQUALIFICATION OF JUDGES: IN SUPPORT OF THE BAYH BILL
}

\author{
JoHN P. FRANK ${ }^{*}$
}

The defeat of Judge Clement Haynsworth, Jr., for the Supreme Court demonstrates that the federal law of disqualification of judges needs to be rewritten. As Justice Blackmun said of a shift in his own personal disqualification practice, "The times have changed."

John Marshall heard Marbury v. Madison although the substance of the case involved problems arising from his own failure to deliver papers when he was Secretary of State in the Madison administration. Justices Byron White and Thurgood Marshall, former Deputy Attorney General and Solicitor General, never hear cases involving matters with which they dealt in the Department of Justice.

The difference is not in the character of the Justices, but in the governing law and the changed attitudes of recent times. In Marshall's day, the law of disqualification was governed by two maxims from the sages. Coke, in the most famous rubric of the law of disqualification, had said, "aliquis non debet esse judex in propria causa," or no man shall be a judge in his own case. ${ }^{2}$ Blackstone had reduced this to a straight matter of pocketbook interest by excluding the possibility of disqualification for bias or prejudice or relationship, "for the law will not suppose the possibility of bias or favor in a judge."

- (Mr. Frank, author of numerous books on the United States Supreme Court, is presently in private practice in Phoenix, Arizona.-Ed.)

tI have been assisted in this article by Mr. John McLamb, a student at Yale Law School. An article on disqualification, above all writings, should acknowledge its biases. At the request of the Judiciary Committee of the United States Senate, I appeared as an expert witness on the matter of disqualification in connection with the Haynsworth appointment. This was because of my article Disqualification of Judges, 56 YALE L.J. 605 (1947) [hereinafter cited as Frank, supra]. On most matters, I trail cheerfully along as a respectful camp follower behind the Democratic Senators, including Senator Bayh, who dissented in the Judiciary Committee to the Haynsworth confirmation. However, to borrow Tennyson's phrase, Judge Haynsworth bears without abuse the grand old name of gentleman, and I testified to an abiding conviction that no significant objection to his confirmation should be made on the basis of disqualification. Hearings on the Nomination of Clement Haynsworth, Jr. to be Associate Justice of the Supreme Court Before the Senate Comm. on the Judiciary, 9rst Cong., Ist Sess. 123 (1970) [hereinafter cited as Haynsworth Hearings]. In the case of Judge Carswell, I signed the leading opposition bar letter, see, e.g., The Washington Post, Mar. $16,1970, \S \mathrm{B}$, at 4 , not because of agreement with its details, but because of a general serise of the unfitness of the appointment.

${ }^{1}$ Hearings on the Nomination of Harry A. Blackmun to be Associate Justice of the Supreme Court Before the Senate Comm. on the Judiciary, 9Ist Cong., 2d Sess. 4I (I970) [hereinafter cited as Blackmun Hearings]. Disqualification is a subdivision of the general area of conflict of interest. I have written of the non-disqualification aspects of conflict of interest, discussing matters concerning Justices Fortas and Douglas and others in the December, 1970, issue of The American Journal of Comparative Law.

I COKE, Institutes *i4ta.

${ }^{3} 3$ Blackstone, Commentaries * $36 \mathrm{r}$. In so saying, Blackstone consciously rejected the earlier views of Bracton, who had said that a judge should disqualify if he were related to a party, if he were hostile 
The nineteenth century changed the rules of the game. At the beginning of the century, pecuniary interest was the only ground of disqualification. By the end of the century, bias and relationship had been added; for a strong suggestion of bias arises from relationship. The judge may be so related to a party or an attorney that he is either actually partial or appears to be. Quite aside from relationship, the judge's former career may preclude a fair approach to the case. The case may have been in his firm and he may have worked on it before he went to the bench. Whether it was or not, the party may be a former client with whom he has had a very close association. It may involve some matter with which he was directly and personally involved when he was in the executive branch of the government. In any of these instances, he may lack a free mind. All of these, with refinements which we may put aside for the moment, have become grounds for disqualification since Marshall's time.

Inevitably, judicial virtue is a mix of ethics and convenience. It draws upon the grand magniloquence of Lord Coke and the Due Process clause. On the other hand, however, school must keep; someone had to decide the cases. The reluctance to sit must be balanced by the principle of necessity, so that, for example, Chancellor Kent sat in his brother-in-law's case because there was no alternative way of deciding the matter anywhere. ${ }^{4}$

This balance has a practical application in the federal system. In the past thirty years, the number of federal judges has radically expanded. Only a few states now have but one federal judge, and the larger cities have such judges by the squadron. Only one court of appeals is limited to three judges. In the larger circuits, the chambers line the halls. The result both can and should be that the standard of disqualification goes up; it is so easy to put someone else on the case.

But in the Supreme Court, this is not true; the number is fixed and there are no substitutes. If even one disqualifies, it may be impossible as a practical matter to reach a decision. If four disqualify, decision is legally impossible. Instances of complete inability to decide for lack of a quorum have occurred. To avoid one such lack of a quorum, after first disqualifying himself in the leading Public Utility Hold. ing Company Act case, Chief Justice Stone withdrew his disqualification so that the case could be decided. 6 Undoubtedly because of the limit on the number of Justices, the Supreme Court Justices have not disqualified casually. On the other hand, where disqualification is clear, out they go.

\section{I}

\section{Tye General Law of Diseualification}

Disqualification is a term generally applied to the process or result by which a

to a party, or if he had been counsel in the case. 4 Bracton, De Lecibus Et Consuetudinibus Angliat 28I (Woodbine ed. I942).

See generally Frank, supra, at 6rx.

$\checkmark 28$ U.S.C. $\$ I(I 964)$.

- North American Co. v. SEC, 327 U.S. 686 (1946). 
judge disengages from participation in a particular case which he would otherwise hear. There is a technical distinction between disqualification or exclusion by force of law, and recusation, or withdrawal at the judge's discretion, but the latter term is now largely obsolete, and I put it aside. ${ }^{7}$ There are two sources of the law of disqualification, the common law and the statutes. But these are to some extent overlaid by the constitutional conception of due process. That is to say, some kinds of disqualification were so absolutely basic that justice would be altogether denied if a judge were allowed to participate in a case. This amounts to what might be regarded as the inner core of disqualification. Surrounding that inner core are the group of further restrictions which are not constitutional, but are simply refinements.

Interest in the proceeding. Illustrative of the constitutional inner core of the law of disqualification is the famous case of Dr. Bonham, ${ }^{8}$ in which Lord Coke said that not even an Act of Parliament can allow a judge to retain a fine which he levies. The case illustrates the axiom that "No man shall be a judge in his own case." The Bonham principle was followed in 1927 , when the Supreme Court held that a judge could not hear a case in which he received a portion of the fine which he imposed.10 The guiding due process principle was more recently restated by the Supreme Court:
A fair trial in a fair tribunal is a basic requirement of due process .... To this end no man can be a judge in his own case and no man is permitted to try cases where he has an interest in the outcome.

The Justices apply the same standard to themselves. What appears to be the first case of disqualification for interest is Livingston \& Gilchrist v. Maryland Insurance Company, which involved the financial interest of someone referred to as B. Livingston of New York. Justice Brockholst Livingston is recorded as absent from the decision. ${ }^{12}$ In Fairfax's Devisee v. Hunter's Lessee, decided the same year, Marshall, who had an interest in the land, was also "absent."13 Chief Justice White, as a recipient of a sugar bounty, disqualified in a case involving that interest. ${ }^{14}$

No one doubts the principle of disqualification for direct interest, although there may be a problem as to how the principle is applied. The possibility of an acci-

\footnotetext{
7 This was a meaningful distinction in the federal system prior to 1949 , when the applicable statute applied only to district judges and not to appellate judges. Appellate judges then frequently applied the statute to themselves. The adoption of 28 U.S.C. $\$ 455$ in that year as a general disqualification statute applicable to all judges makes this term of no consequence now. For discussion of these distinctions between House Judiciary Chairman Hobbs and Chief Justice Stone, see A. Mason, HarLAN Fiske Stone 702-03 (1956).

${ }^{8} 8$ Co. 107a, 77 Eng. Rep. 638 (K.B. 1608).

- I COKE, INSTITUTES *I4Ia.

${ }^{20}$ Tumey v. Ohio, 273 U.S. 510 (1927).

${ }^{21}$ In re Murchison, 349 U.S. 133 , 136 (I955).

12 II U.S. (7 Cranch) 506 (I813). The connection, or indeed, the possible identical personality, of the Livingston's referred to is not clear from the report.

${ }^{18}$ II U.S. (7 Cranch) 603 (1813); see Martin v. Hunter's Lessee, I4 U.S. (I Wheat.) 304 (1816).

16 United States v. Realty Co., I63 U.S. 427 (I896).
} 
dental deviation, as in the case of Judge Haynsworth discussed elsewhere in this essay, is perfectly real. Some Justices are wealthy men, with wide holdings. The list of parties may be long. The designation "et al." though short, is a cloak large enough to cover twenty or more parties in a mortgage foreclosure. Equally troublesome is the problem on the horizon which results from holding companies or corporate affiliations through conglomerates. There is nothing published on the practices of the Justices where a Justice may own a small amount of stock in a company which in turns owns stock in a party, or where any of the other possible corporate permutations exist. I believe that there is disqualification in those cases although, inevitably, there must be error where the Justice simply does not know. Prior to I948, there was no federal statute which laid down any disqualification requirements for Justices of the Supreme Court. The statutes then in existence were restricted to district judges, though the practice at the Supreme Court was for the Justices largely to apply to themselves the same standards as existed in the statutes. ${ }^{16}$ The current statute, as adopted in I948, does apply to the Supreme Court as well as to the lower courts, requiring the Justices to disqualify in the case of "a substantial interest."16 Nothing is written as to how the Justices have applied the concept of "substantial" to themselves, but I believe that they have disqualified where they have felt that they had any interest at all.

Relationship to a party or counsel. Relationship makes so well-accepted a conflict of interest that it is a standard ground of disqualification. If the relationship is lineal, as for example a son and a father, there may be the possibility of an inheritance. In any case, there is the possibility of bias, and certainly there is the appearance of bias. Yet, the matter has its fuzzy edges: Is the relationship with the party or with the attorney? If with the attorney, is a relationship to Partner $A$ in a large office sufficient ground to disqualify when Partner $B$ handles a case? Does it matter whether the attorney's fee is contingent? The federal statute abandons any effort at precision, simply requiring disqualification if the Justice "is so related to or connected with any party or his attorney as to render it improper, in his opinion, for him to sit."17 The matter gets its final and largest complication from the problem of how close the relationship must be. As was said in a 1572 decision, "All the inhabitants of the earth are descended from Adam and Eve, and so are cousins of one another," but "the further removed blood is, the more cool it is."18 While in that case the line was drawn at relationship in the ninth degree, American practice has cut it off at various points between the third and the sixth degrees. ${ }^{19}$

The Supreme Court practice has shifted from the nineteenth to the twentieth

\footnotetext{
${ }^{15}$ See Testimony of Chief Justice Stone, Hearings on H.R. 2808 Before the House Comm. on the Judiciary, 78th Cong., Ist Sess. 24 (I943).

${ }^{10} 28$ U.S.C. $\$ 455(1964)$.

${ }^{17}$ Id.

${ }^{18}$ Vernon v. Manners, 2 Plowden 425, 75 Eng. Rep. 639 (K.B. 1572).

${ }^{19}$ Frank, supra, at 616 .
} 
centuries. In the nineteenth century, Justices Curtis and Field on various occasions heard cases presented by their brothers, and Justice Miller heard his brother-in-law. In the twentieth century, the line has hardened. Solicitor General Hughes resigned when his father became Chief Justice, and Chief Justice Stone would hear argument in a case his son had tried only upon the consent of the parties, and that in one highly exceptional case. ${ }^{20}$ However, in that instance, while the son had been counsel in the Military Commission proceedings which the Supreme Court was to review, he was not involved in any way in the Supreme Court proceedings.

The Solicitor General is so actively involved in presenting cases to the Supreme Court that something like the Hughes solution was required as to that office. Other relationships between the Court and the Department of Justice, however, might well be different. The Department's problem is special because it is the largest law office in the world and has cases by the hundreds of thousands and lawyers by the thousands. For the most part, the relationship of the Attorney General to most of those matters is purely formal. As between the Assistant Attorneys General for the various Departmental divisions, there is almost no connection.

This was a problem of the Clarks, pere et fils, because each rose through the chairs of the Department of Justice, and son Ramsey was moving through his chairs while father Tom was on the Supreme Court. When the son was Assistant Attorney General for the Lands Division, and even when he was Deputy Attorney General and thus the number two man in the Department, the father did not disqualify himself. However, when the son moved from the office of Acting Attorney General to the full and formal post of Attorney General, the father resigned from the Supreme Court.

Justice Clark could have made his decision either way. While there is no previous case of a Justice father-Attorney General son relationship, there is one relationship even closer than this, and that is the relationship of the Justice to himself. In repeated instances, Attorneys General rise to the Supreme Court, and they must then decide whether they can sit on cases which were in the Department when they themselves were there. This is decided on a case-by-case basis. Repeatedly, Attorneys General have sat in such cases where they felt that their connection with the matter in the Department was purely nominal. An illustration of the subjectivity of the practice is Schneiderman v. United States, ${ }^{21}$ a denaturalization matter during World War II so important that the then most recent Republican Presidential candidate, Mr. Wendell Willkie, presented the case for Schneiderman. The opinion of the Court in this closely divided case was written by Mr. Justice Murphy. Justice Jackson disqualified with a brief statement which matched its hostility to Justice Murphy only with its subtlety. Jackson said, "This case was instituted in June of I939 and tried in December of that year. In January, I940, I became Attorney General of the United

\footnotetext{
${ }^{20}$ Ex parte Quirin, 3 I 7 U.S. I (1942).

${ }^{21} 320$ U.S. 118 (1943).
} 
States and succeeded to official responsibility for it. This I have considered a cause for disqualification, and I desire the reason to be a matter of record."22

This gratuitous reproof to Murphy, who had been the Attorney General in 1939, did not mean that Jackson always disqualified himself when he felt that his participation was only a formality. In one instance, in reversing an opinion which he had personally signed when he was Attorney General, Jackson hints that he had been merely the nominal author of the disputed Attorney General's opinion. ${ }^{23}$ Chief Justice Stone suggested that the proper standard of disqualification was whether a former Attorney General had "something more to do with the case than the merely pro forma relations which an Attorney General often has with cases in the Department of Justice."24

Nonetheless, Justice Clark, a man immensely sensitive to the value of high ethical appearance as well as its substance, resigned. There was in fact no functional difference between the son's relationship to the Supreme Court as Deputy Attorney General or, certainly, as Acting Attorney General, a post he held for a long time, and his final position as Attorney General. ${ }^{25}$

Personal bias. The final ground for disqualification is bias. As used in a standard dictionary, the phrase denotes a "propensity or prepossession or bent." So far as the legal issue in the particular case is concerned, that is not what the term means in the federal law of disqualification. ${ }^{26}$ Supreme Court Justices are strong-minded men, and on the general subject matters which come before them, they do have propensities; the course of decision cannot be accounted for in any other way. ${ }^{27}$ Nor can bias be based upon rulings in the particular case $;^{28}$ the general federal view is that the bias must be "of extra-judicial origin." ${ }^{29}$ Bias in this sense means that bias which arises from the judge's association with either an attorney, a party, or the government.

\footnotetext{
29 Id. at 207 .

${ }^{23}$ McGrath v. Kristensen, 340 U.S. I62 (1950).

24 Hearings on H.R. 2808 Before the House Comm. on the Judiciary, 78th Cong., 1st Sess. 124 (1943).

${ }^{25}$ In all cases involving the Federal Communications Commission, Justice Black disqualificd during the period that his brother-in-law, Mr. Clifford Durr, was a member of the Commission. See, e.g., FCC v. Woko, Inc., 328 U.S. 223 (1946). However, in the FCC case, Mr. Durr necessarily participated in a judicial capacity in the very matter under Supreme Court review. Judge Learned Hand considered it appropriate to review decisions of his cousin, Judge Augustus Hand, when the former was a circuit judge and the latter a district judge. See, e.g., New York \& Albany Lighterage Co. v. Bowers, ${ }_{4}$ F.2d 604 (S.D.N.Y. I925), affd, Io F.2d Ior7 (2d Cir. I926).

${ }^{20}$ See generally Schwartz, Disqualification for Bias in the Federal District Courts, II U. PITT. L. REv. 415 (I950).

${ }^{27}$ For a documented development of the application of the "philosophy" of the Justices to antitrust cases, see the discussion by Stern, Commentary, 38 Antitrust Journni, 602, 608-09 (1969). Mr. Stern illustrates that in a period in which Justices Harlan and Stewart have divided about fifty-fifty for and against the plaintiffs and the defendants in the antitrust cases, Chief Justice Warren in sixty consccutive government antitrust cases voted in favor of the government fifty-nine times. He obviously has a strong "bent."

${ }^{28}$ Ex parte American Steel Barrel Co., 230 U.S. 35, 44 (I9r3); Berger v. United States, 255 U.S. 22, 34 (I92I).

${ }^{29}$ Craven v. United States, 22 F.2d 605, 607 (Ist Cir. I927); Price v. Johnston, I25 F.2d 806 (9th Cir. I942). I attempted to advance a more liberal view of this ground of disqualification as special counscl
} 
Apart from interest and relationship, it has not been the practice for Supreme Court Justices to disqualify because of attorney contacts except for those contacts arising from some sort of joint involvement in a particular matter. Each Justice will inevitably have friends at the bar, and some of them are very close. This, by itself, is never a ground of disqualification in the Supreme Court. ${ }^{30}$ Ex-members of the Court may also appear-Justices Curtis, Campbell, and Hughes often did.

A problem does arise if the attorney is a former partner and if he is presenting a matter which was in the Justice's office before he went to the Court. In that circumstance, the Justice invariably disqualifies, as do all judges. On the other hand, if the attorney is a former partner but the matter was not in the office at the time the Justice withdrew, then there is no disqualification. While Justice Jackson once very sharply criticized Justice Black for having heard a case presented by a man who had been his partner more than twenty years before, the episode is regarded as an aberration on the part of Justice Jackson, who was at the time under great strain in connection with his extra-judicial duties as War Crimes Prosecutor at Nuremburg. The fact is that no Justice has ever disqualified himself because a matter was being presented by an ex-partner. Illustrations of Justices who did not disqualify in such circumstances are Holmes, Brandeis, Cardozo, and Stone. ${ }^{31}$

The matter of the case in the office bridges over into party contacts, because the real reason that the Justice does not sit in such circumstances is because either he or his office has represented the party in the litigation in the particular matter. As noted, disqualification is universal when the case was in the office; the federal statute expressly provides that the Justice shall disqualify in any matter in which he "has been of counsel," and if his firm was of counsel, so was he. But what shall be done as to the former client? May a Justice sit when the case was not in the office, but the party was, so that the Justice has in fact represented that particular concern in other matters previously? Here the practice is very sharply divided. Justice Stone felt that it would be "undesirable" for "a member of the Supreme Court to sit in a case of a client of his former firm, even though his relations with the client had not been at all personal," and even though the particular matter was not in the office at the time..$^{32}$ But the weight of the practice has been the other way, and Justices who

on a petition for certiorari in DePinto v. Provident Security Life Insurance Company, but to no avail. See 374 F.2d 37 (9th Cir.), cert. denied, 389 U.S. 822 (1967).

${ }^{30}$ See Frank, supra, at 621-22. I have had pleasant personal relations with most of the Justices, in varying degrees of closeness, over the past thirty years. As one of them has cheerfully said, "I can decide a case against you as well as against anyone else," and quite so. However, I have scrupulously sought to avoid my social contact with a Justice except in the presence of opposing counsel around the time of an argument, and have felt something of a twinge of embarrassment in accidentally finding myself at dinner with one of the Justices on the evening before a case was to be presented.

a1 The bizarre attack of Justice Jackson is exhaustively considered in Frank, supra, a study which was occasioned by that event.

${ }^{32}$ Frank, supra, at 623-24. Mr. Justice Blackmun agrees with Justice Stone on this point although he seems to set a limit at cases involving former "regular" clients. Blackmun Hearings 45. 
have previously represented particular corporations have later felt quite free to hear cases involving those same concerns on independent matters. ${ }^{33}$

In contemporary times, Justices more frequently come from the government than from private practice. On the present Court this was true of Chief Justice Burger, and Justices Black, Douglas, White, and Marshall. When I wrote in 1947, eight of the nine members of the Court had distinguished government backgrounds.

Justices disqualify in government cases when they have been directly involved in some fashion in the particular matter, and not otherwise. Illustrations from the Department of Justice were given earlier. The disqualification is limited to the particular department with which the person has been connected-that is to say, Justice Goldberg did not disqualify in a non-labor case coming from the Department of Justice when he was Secretary of Labor. Any other rule would make it useless to appoint government lawyers at all. More important, Justices who have come from the government do not disqualify merely because the particular matter involves a policy which, when in the government, they may have helped to form. The Justices who come from the House or the Senate do not disqualify from the interpretation of statutes which they may most actively have helped to write. Chief Justice Vinson wrote on tax matters and Justice Black on Fair Labor Standards Act cases, though each was particularly involved with those laws. Other examples could be endless. Chief Justice Taney achieved the most eccentric compromise on record. As Attorney General he had given the Secretary of the Treasury an opinion on a particular matter of federal relations of the Bank of the United States. When a case came along involving the same subject, he did not sit, but he filed an unofficial dissent in the appendix of the reports. ${ }^{34}$

In short, Supreme Court Justices disqualify when they have a dollar interest; when they are related to a party and, more recently, when they are related to counsel; and when the particular matter was in one of their former law offices during their association; or, when in the government, they dealt with the precise matter and particularly with the precise case; otherwise, generally no.

Federal statutes and practice. In the country as a whole, there are two conflicting currents on disqualification. In some states, disqualification is easy; for example, in Arizona, the author's state, one may have one change of judge almost for the asking. A simple affidavit will do it. In others, disqualification is hard-one must squarely show interest, relationship, or bias or keep the judge he has.

The federal practice tends to the latter view. Originating in a period of few judges, perhaps one in a state, where disqualification might well mean long delay, casual disqualification was not much welcomed. This is reflected in the two federal statutes:

\footnotetext{
${ }^{83}$ Mr. Justice Goldberg did disqualify in some labor cases when he had been associated previously with a party. See United Steelworkers of America v. NLRB, 376 U.S. 492 (1964); United Steclworkers of America v. R.H. Bouligny, Inc., 379 U.S. 958 (1965).

${ }^{34}$ Bank of the United States v. United States, 43 U.S. (2 How.) 7II, 745 (I844).
} 
r. 28 U.S.C. $\$ 455$ :

Any justice or judge of the United States shall disqualify himself in any case in which he has a substantial interest, has been of counsel, is or has been a material witness, or is so related to or connected with any party or his attorney as to render it improper, in his opinion, for him to sit on the trial, appeal, or other proceeding therein.

\section{28 U.S.C. $\$$ I 44 :}

Whenever a party to any proceeding in a district court makes and files a timely and sufficient affidavit that the judge before whom the matter is pending has a personal bias or prejudice either against him or in favor of any adverse party, such judge shall proceed no further therein, but another judge shall be assigned to hear such proceeding ....

Particularly in the federal practice, the judge has an equal duty to disqualify when he should and to sit when he should. "It is a judge's duty to refuse to sit when he is disqualified but it is equally his duty to sit when there is no valid reason" not to. ${ }^{35}$

\section{II}

\section{Major Disqualification Matters Raised as to Judge Haynsworth}

Judge Clement Haynsworth, the Presiding Judge of the Fourth Circuit and President Nixon's choice to succeed Justice Fortas, was opposed by civil rights and labor organizations. While these groups could muster a substantial number of Senate votes, they could not, on those grounds alone, defeat the nomination. They therefore turned their attention to conflict of interest charges, and the marginal number of votes sufficient to defeat the nomination came from this source. The conflict of interest issues were essentially disqualification problems; the question was whether the Judge should have disqualified himself in certain matters which came before him on the Court of Appeals.

\footnotetext{
${ }^{55}$ See Edwards v. United States, 334 F.2d $360,362 \mathrm{n.2}$ (5th Cir. 1964), a case in which the judge clearly regretted that he could not withdraw. This is the general federal view. Cases to the foregoing effect, grouped by circuits, are: D.C. Circuit: Tynan v. United States, 376 F.2d $76 \mathrm{r}$ (D.C. Cir. 1967); United States v. Hanrahan, 248 F. Supp. 47 I (D.D.C. 1965); Ist Circuit: In re Union Leader Corp., 292 F.2d $38 \mathrm{I}$ (Ist Cir. I96I), cert. denied, 368 U.S. 927 (I96I); $2 d$ Circuit: Wolfson v. Palmieri, 396 F.2d r2I (2d Cir. I968); Rosen v. Sugarman, 357 F.2d 794 (2d Cir. I966); Town of East Haven v. Eastern Airlines, Inc., 293 F. Supp. 184 (D. Conn. I968); Cranston v. Freeman, 290 F. Supp. 785 (N.D.N.Y. I968); United States v. Devlin, 284 F. Supp. 477 (D. Conn. I968); $3 d$ Circuit: Simmons v. United States, 302 F.2d 7I (3d Cir. I962); United States v. Valenti, r20 F. Supp. 80 (D.N.J. I954); 5th Circtit: Edwards v. United States, supra; 6th Circuit: United States v. Hoffa, 382 F.2d 856 (6th Cir. I967); Pessin v. Keeneland Association, 274 F. Supp. 513 (E.D. Ky. I962); 7th Circuit: Tucker v. Kerner, I86 F.2d 79 (7th Cir. 1950); In re Federal Facilities Realty Trust, I40 F. Supp. 522 (N.D. Ill. I956); 8th Circuit: Walker v. Bishop, 408 F.2d 1378 (8th Cir. 1969); United States v. Love, 259 F. Supp. 947 (D.N.D. I966); gth Circuit: United States v. Shibley, I12 F. Supp. 734 (S.D. Cal. I953).
} 


\section{A. The Darlington Case}

The first charge against Judge Haynsworth arose from his participation in NLRB v. Darlington Manufacturing Company. ${ }^{36}$ Deering Milliken Company in the early Ig6os was a largely Milliken-family-held textile selling house. It was also what can be loosely called a holding company, owning or dominating seventeen textile manufacturers which had twenty-seven plants. One of those plants was Darlington Manufacturing Company, in which the Deering Milliken group held a majority, but by no means all, of the stock. Darlington fell into conflict with the Textile Workers Union in 1956 and went out of business. The broad legal question was whether Darlington had committed unfair labor practices, and if so, whether Deering Milliken should be held financially responsible.

Judge Haynsworth, when the matter reached his Court, was a substantial stockholder in Carolina Vend-A-Matic Company, a vending machine company which sold coffee and other refreshments. This company had "locations" in many places, including three of the twenty-seven Deering Milliken affiliates. The locations were obtained by competitive bidding. Deering Milliken did not pay Vend-A-Matic to come to the premises-Vend-A-Matic paid a premium to Deering Milliken, if anything was paid. It had nothing to do with Darlington. Revenues from those plants amounted to about three per cent of the vending company's income.

When the case came before the Fourth Circuit Court of Appeals, the judges concluded that its importance warranted hearing by all of the five circuit judges, of whom Judge Haynsworth was one. The Court decided three to two that there was no unfair labor practice, with Judge Haynsworth in the majority. Hence, it never reached the question of whether Deering Milliken was chargeable with the cost. The Supreme Court held that there might have been an unfair labor practice, depending upon facts which were not in the record, and that the Labor Board's opinion was not comprehensive enough to cover the case. It therefore vacated the decision of the Court of Appeals with instructions to send the case back to the Labor Board for further proceedings. On this remand, the Board found unfair labor practices, and the Court of Appeals, Judge Haynsworth concurring specially, enforced the order. ${ }^{37}$

In late 1963 , the Textile Workers Union of America, on the basis of an anonymous telephone call received by it, forwarded an allegation to Judge Sobeloff, the Chief Judge of the Fourth Circuit, charging improper inducements by Deering Milliken to Judge Haynsworth. Judge Haynsworth asked for a full-scale investigation and consideration, both by the circuit judges and the Department of Justice. On February 6 , I964, the Union, after the investigation, withdrew its complaint with warm apologies. The Court of Appeals judges, after independent investigation, concluded that there was "no warrant whatever" for the charge. Similarly, Attorney General Kennedy expressed his "complete confidence" in Judge Haynsworth.

\footnotetext{
${ }^{80} 325$ F.2d 682 (4th Cir. 1963 ).

${ }_{87} 397$ F.2d 760 (4th Cir. I968).
} 
Clearly, if there were any basis whatsoever for the anonymous suggestion of improper inducement, Judge Haynsworth should not be considered for any post. But there is not, and the call may be put aside as one of those unhappy prices which judges must sometimes pay for the vexation of disappointed litigants. There remains, however, the question as to whether Judge Haynsworth should have disqualified himself in the case.

If Judge Haynsworth were to have disqualified in this case, it would necessarily have been for interest. That is to say, there is no conceivable question of relationship or bias, apart from interest, as those terms are used in the law. ${ }^{38}$ Under what circumstances, if any, must a judge who is a shareholder of a company which has business dealings with a party, disqualify himself from hearing a case involving that party?

I. It is immaterial that Judge Haynsworth was a shareholder in the vending company rather than owner of the company in a personal proprietary capacity. The law of disqualification, in the heavy majority and clearly better view, treats a shareholder as though he individually were the concern in which he holds shares. In other words, if a judge holds shares in a corporation which is in fact a party before him, he should disqualify as much as if he himself were a party. ${ }^{39}$ Every state and federal court reporting agrees that if the judge has a pecuniary interest in the party, he may not sit.

2. Where the judge has an interest in a non-party, however, the rules are entirely different. This is a necessary concession both to common sense and to the practicalities of modern life. Lines must be drawn somewhere. Thus, at common law, a judge might have disqualified in a case involving taxes in an area in which he paid. But this is not the modern view. ${ }^{40}$ In these non-party cases, the rule of disqualification which has developed is a test of immediacy or remoteness of the interest. The interest must be direct, proximate, inherent in the instant event, and affected by the direct outcome of the particular case. ${ }^{41}$ It must be direct, real, and certain; and not incidental, remote, contingent, or possible." The interest contemplated is a "pecuniary or

\footnotetext{
${ }^{88}$ We may for other reasons put aside 28 U.S.C. $\$ 144$; not only does it relate solely to district courts, but it requires an affidavit procedure, and it is restricted to bias.

${ }^{30}$ This is the clear majority rule. See Annot., 48 A.L.R. 617 (1927), updated in a comprehensive collection at 25 A.L.R. 3d $133 \mathrm{I}$ (1969). There are some refinements where the holding is very small. See, e.g., Lampert v. Hollis Music, Inc., ro5 F. Supp. 3 (E.D.N.Y. I952) (20 shares of 13,881,016). See also Frank, supra, at 637 , reporting that in 33 state and federal courts there is disqualification in such circumstances, but that two state and two federal courts reported that disqualification might be waived where the holding was very slight, and one federal court reported that a judge had sat where the holding was very slight. I shall return to this subject in detail below. Nonetheless, the view is overwhelming. There are also refinements not necessary to be considered here when the stock is held by a member of the judge's family. See Note, 4 MrnN. L. REv. $30 \mathrm{I}$ (I920). See also Goodman v. Wisconsin Elec. Power Co., 248 Wis. 52, 20 N.W.2d 553 (1945).

${ }^{10} \mathrm{My} 1947$ article shows no judges disqualifying because they are taxpayers, and only two areas in which they disqualified because they would be affected by public utility rates. Frank, supra.

${ }^{\star 1}$ Goodspeed v. Great Western Power Co., I9 Cal. App. 2d 435, 444, 65 P.2d I342, I345 (I937).

${ }^{49}$ See 48 C.J.S., Judges at 1048.
} 
beneficial interest" in the case, ${ }^{43}$ with equal attention both to the benefit and to its connection with the particular case. ${ }^{44}$ Some cases push this to the point of saying that in order to be disqualified for interest in these third party situations, the judge must be capable of being made an actual party to the case, but this is not the better view, which is that it is sufficient if he has a proprietary interest in the actual result of the actual case. ${ }^{45}$

3. Coming then squarely to the problem of judges who in some manner have financial relations with a party, the question may arise when the judge is connected with a supplier, as was Judge Haynsworth, or with a creditor or debtor of the party. These problems have been solved in the manner foreshadowed by the foregoing principles. If the interest of the judge as creditor, debtor, or supplier will in any way be affected by the case, then he must disqualify. Otherwise, he should not. For example, when there was a dispute over a corporate election in Corporation $A$, which in turn has a large claim against Corporation $B$, in which the judge is a shareholder, the judge was held disqualified to pass on the election because he would in effect be choosing who was to be in control of a lawsuit against him. ${ }^{40}$ Similarly, where a judge was a stockholder in a bank which was a substantial creditor of plaintiff and plaintiff's repayment to the bank was dependent upon a judgment in the particular case, the judge was disqualified. ${ }^{47}$ On the other hand, where there is no direct effect in any meaningful way, the judge is not disqualified. Thus, a judge who was a stockholder but who would not be affected by the final outcome was not disqualified. ${ }^{48}$

The Supreme Court of Michigan has emphatically rejected a view that a judge who is a shareholder of a creditor of a party, even on a substantial obligation, is disqualified in the absence of a showing of some direct and precise benefit to the creditor from the case. A suggestion to the contrary is said to have "no foundation in reason." 49

A leading case very close to the supply situation is Webb v. Town of Eutaw, ${ }^{\text {bo }}$ in which the judge was a stockholder in a bank to which a party was indebted. The Alabama court, in holding no disqualification, laid down the guiding rule

\footnotetext{
43 United States v. Bell, 35 I F.2d 868, 878 (6th Cir. I965); Edwardson v. State, 243 Md. I3I, 220 A.2d 547 (Ig66).

"Beasley v. Burt, 20 r Ga. I44, 39 S.E.2d 5 I (r946).

${ }^{45}$ Hall v. Superior Court, I98 Cal. 373, 245 P. 8r4 (I926) (judge owned property in an irrigation district immediately involved in litigation). For a view requiring a party capacity, see Central Pac. Ry. Co. v. Superior Court, 2 II Cal. 706, 7r9-20, 296 P. 883, 888-89 (I93I). The proper test is whether the third party has a "present proprietary interest in the subject matter." City of Vallejo v. Superior Court, $199 \mathrm{Cal}$. $408,4 \mathrm{I} 6,249$ P. $\mathrm{ro8}_{4}, \mathrm{x}^{0} 87$ (r926). If so, the judge is disqualified or worse. In Anonymous, I Salk. 396 , 9r Eng. Rep. 343 (K.B. I698), the judge was "laid by the heels" for sitting in an ejectment case when he was lessor of the plaintiff.

${ }^{48}$ Bentley v. Lucky Friday Extension Mining Co., 70 Idaho 5Ir, 223 P.2d 947 (1950).

${ }^{47} \mathrm{See}$ Jones v. American Cent. Ins. Co., 83 Kan. 44, I09 P. 1077 (IgIo).

${ }^{48}$ See Dial v. Martin, 37 S.W.2d I66 (Tex. Civ. App. r93I); Adams v. McGehee, 21I Ga. 498,86 S.E.2d 525 (1955).

${ }^{60}$ In re Farber, 260 Mich. 652, 66r, 245 N.W. 793, 795 (I932).

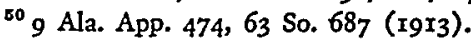


that the mere existence of "a business relation with one of the parties to [the case] is to be regarded as too remote or contingent to constitute a ground of disqualification." The judge must disqualify only where the corporate creditor in which he is a stockholder has "a direct and immediate interest in the result of the suit."

4. The principles just outlined are codified in the controlling federal statute, 28 U.S.C. $\$ 455$. The judge is disqualified "in any case in which he has a substantial interest" in the particular case. ${ }^{52}$

A judge with an interest in a third party which in turn has business relations with a party to a case is not disqualified for interest unless the case directly affects the third party. Any contrary result would lead to impossible consequences. If, hypothetically, a judge owned stock in a major automobile company, he would be disqualified from hearing auto accident cases if a party happened to be a regular purchaser of cars manufactured by "his" concern. In the Darlington case, the issue was a determination of an unfair labor practice involving a subsidiary of a large concern which had no connection except common ancestry with other plants which Vend-A-Matic serviced. The concessionaire did business, not with Deering Milliken except as it paid for the privilege of installing machines, but with its employees. The proportion of its revenue from this source was slight. There was no issue in the case which related even in the most fanciful degree to coffee and food distribution by Vend-A-Matic. A review of all of the reported cases on disqualification in the United States shows no instance in which a judge has ever disqualified in circumstances in any way similar to the Haynsworth situation.

In the instant case, it was necessary to have all of the judges of the Circuit participate; it was an en banc determination. Had Judge Haynsworth not participated, the Court would not have been able to decide the case at all. But regardless of that circumstance, since he was not disqualified, it was, under the strict federal rule of duty, his plain responsibility to participate, and he would have shirked his duty under existing law if he had not done so. ${ }^{53}$ In these circumstances, a majority of the Senate Judiciary Committee concluded that the conduct of the Judge in participating in this (and other cases involving vending customers) was quite proper. On the other hand, Senator Bayh felt that his participation violated "the strong precedents of disqualification law and the canons of judicial ethics on this subject."

\footnotetext{
${ }^{52}$ Id. at 477,63 So. at 688 . The same problem arises when municipal bodies are called upon to award contracts for public works. It is frequently held that the mere fact that a municipal officer is a shareholder in a supplier of a contractor is not a disqualification'. See O'Neill v. Town of Auburn, 76 Wash. 207, I35 P. 1000 (I913).

${ }^{2}$ As was said of a third-party involvement under an earlier form of the statute, where the judge as shareholder of a creditor was wholly unaffected by the case, the interest to disqualify may be "so slight or inconsequential that the rights of the parties would be best subserved by his proceeding with the cause. ..." Utz \& Dunin Co. v. Regulator Co., 213 F. 3I5, 3I8 (8th Cir. 19I4).

${ }^{83}$ See note 35 supra.

"Haynsworth Report, S. Exec. Rep. No. 9I-92, 9Ist Cong., Ist Sess. 34 (I969).
} 


\section{B. Brunswick Corporation v. Long: The Problem of Minor Stock Ownership}

Not much was made of the Darlington matter in the final analysis except as it had cumulative weight. Far more troublesome for the nominee was Brunswick Corporation v. Long.5 Brunswick was an appeal involving a minor point of law. It was heard on November ro, 1967 , before a panel of three judges including Judge Haynsworth. The Court on that day concluded to affirm the trial court's decision in favor of Brunswick. The opinion was assigned to one of the other judges.

On December 20, I967, Judge Haynsworth's stockbroker purchased for him some $\$ 16,000$ worth of Brunswick stock. At that time, the Judge was aware that the purchase was being made. He was not aware, however, that the formal opinion in the Brunswick case had not yet come out. Later, the judge to whom the opinion had been assigned circulated a draft which was accepted by Judge Haynsworth, and the opinion was released in February, rg68. No one suggests that Judge Haynsworth used any inside knowledge gained through the case to decide the matter, or that the decision of the case would in any significant way affect the value of the stock. However, Judge Haynsworth, while he was not aware that the case was pending when he bought the stock, was aware that he had the stock when the opinion came to him for his acceptance.

The Brunswick case thus presents an odd variant of a problem mentioned earlier, the problem of participation by inadvertence. The special wrinkle here was that the stock was acquired after the event. The more general and common problem in the case is the effect on disqualification of holdings of minor amounts of stock. The $\$ 16,000$ worth of stock represents a considerable number of shares, but in the entire eighteen million shares in the company, the number is not significant.

The general American view discussed earlier is that a judge should disqualify if he has any stock in a party. There has been some contrary view when the stockholding was regarded as extremely small. My 1947 article was based in part on an actual poll of the senior circuit judges and the state chief justices. While the heavy majority responded unequivocally that any shareholding was a disqualification, there was some limiting comments. Four courts, in notes added to their responses, said that the practice has been in terms of waiver. For example, Judge Biggs, reporting from the Third Circuit said:

In some cases where the stockholding is infinitesimal the fact of stockownership is stated to counsel in open court and the judge states that he will not sit if either party desires him not to. In every case which has come to my attention counsel has invariably asked the judge to sit.

The responses of the First Circuit, the State of Delaware, and the State of Utah were to the same effect.

Two courts accepted the position now taken by the Fifth Circuit in the cases set forth below. The Chief Justice of New Hampshire responded:

\footnotetext{
${ }^{65} 392$ F.2d 337 (4th Cir. I968), cert. denied, 39I U.S. 966 (1968).
} 
Where the corporate party is a very large corporation and the judge owns so few shares of stock that the outcome of the case will not affect him financially, he does not usually disqualify.

Somewhat more elaborately, the Chief Justice of Michigan said:

I have recommended the practice I have followed on the interest of the judge. When the amount involved in the litigation is very small, the number of his shares when compared with the total issue is also small, so that the amount for which the corporation might be held, would have almost a negligible effect on the shares held by the judge, I have always sat. If there might be a very slight effect on my interest, I have refused to sit, unless requested by all parties, in writing, the clerk of the court telling them by letter of my interest. If however I believe that the outcome might affect my interest to any appreciable extent, I absolutely refuse to sit, though $I$ have often been so requested by the lawyers. The ABA Canons of Judicial Ethics are archaic and passed at a time when municipal bonds, mortgages, etc. giving a fair return were available.

In I968, the Fifth Circuit took the view that, in cases of small stockholding, the judge need not disqualify. ${ }^{56}$ While the Haynsworth matter was pending, the question came up anew in that Circuit. In this more recent response, the Court achieved the unusual result of holding that ownership of stock in a party by two of the three judges provided no basis for disqualification, while nonetheless assigning the case to a different panel. ${ }^{57}$ Eighth Circuit practice was similar to that of the Fifth. Judge Blackmun also sat in small holding cases and, in a direct parallel to Brunswick, once bought stock in a party before a case was out of his court. ${ }^{58}$ The American Bar Association Canons of Ethics adopted the view that in the case of any stockholding, the judge should disqualify. ${ }^{59}$

Judge Haynsworth himself accepts the majority view. He testified expressly that if he had been aware that the Brunswick case was still in his court, he "would not have bought the stock," and that in light of the experience, if he were to buy stock in the future, he would "check the cases that had been heard in his court and were not disposed of" to avoid such a problem. ${ }^{60}$ Brunswick was an eminently forgettable matter. Judge Haynsworth did become aware of the situation before the opinion came down. Whether the best thing to do was to require the case to be reargued before a new panel or let it be decided, was a point of judgment, not rising to a level of ethics.

\footnotetext{
${ }^{60}$ Kinnear-Weed Corp. v. Humble Oil \& Refining Co., 403 F.2d 437, 440 (5th Cir. I968). The decision rests upon the fact that the interest is not "substantial" and holds in effect that the addition of this word to the statute in 1948 changed its meaning.

${ }^{67}$ Austral Oil Co. v. Federal Power Commission, No. 27492 (5th Cir., filed Oct. I7, I969).

${ }^{68}$ Blackmun Hearings 19,46 . The Blackmun matter is discussed below.

${ }^{80}$ ABA Comm. ON Professional Ethics, Opinions, No. I70 (1957).

${ }^{60}$ Haynsworth Hearings $27 \mathrm{r}$.
} 


\section{Farrow v. Grace Lines, Inc.; Donohue v. Maryland Casualty Co.; and Maryland Casualty Co. v. Baldwin ${ }^{61}$}

These three cases involved the same legal problem. In Grace Lines, Judge Haynsworth owned three hundred shares of eighteen million of the parent company which held stock in the party litigant. In the two Maryland Casualty cases, he held sixtyseven of four and one-half million shares of common stock and two hundred of three and one-third million shares of preferred stock, again in the parent company. The question was whether it was proper to sit in those cases.

There is a view, supported by the decision of the California Supreme Court in Central Pacific Railway v. Superior Court, ${ }^{62}$ that the interest must be in the actual party, and that an interest in a parent company is too remote. While the case does so hold, I doubt that it is good law in California, for it conflicts in principle with a better-reasoned case from the same court. ${ }^{63}$ One must blind his eyes to reality to deny that holding stock in a parent is much the same thing as holding stock in a subsidiary.

While in the author's mind, the issue of disqualification in these cases cannot properly be decided on the authority of the Central Pacific case, it may very well be decided in favor of participation on the authority of the Fifth and Eighth Circuit practice discussed above. The federal statute expressly requires that the judge not merely have an interest, but that he have a "substantial" interest. Moreover, this must be an interest in the particular case. Irrespective of whether Judge Haynsworth's stockholdings in the Grace Lines and Maryland Casualty cases are regarded as holdings in a parent or a party, the interest in the cases is quite insubstantial.

It is the better view, I think, that a judge should not sit in any case in which he has even one share of stock in a corporate party, or for that matter, in a parent. If I were making the law, then without hesitation that is the law I would make. On the other hand, if one takes the view of the Chief Justice of the Supreme Court of Michigan quoted above, then we do have a matter of a small case in which "the number of his shares when compared with the total issue is also small," and the result would have "a negligible effect on the shares held by the judge." If one takes this view, then it was proper for Judge Haynsworth to sit.

\section{III}

\section{The Appearance of Impropriety: The Commonwealth Coatings Case}

Existing Canon 4 of the ABA Canons of Judicial Ethics prescribes that " $\mathrm{A}$ judge's official conduct should be free of impropriety and the appearance of impropriety." In I940, this was extended by Committee opinion to apply to judicial

\footnotetext{
${ }^{01}$ Farrow v. Grace Lines, Inc., $38 \mathrm{I}$ F.2d 380 (4th Cir. I967); Donohue v. Maryland Casualty Co., 363 F.2d 442 (4th Cir. I966); Maryland Casualty Co. v. Baldwin, 357 F.2d $33^{8}$ (4th Cir. 1966).

${ }^{02} 21$ I Cal. 706, 719-20, 296 P. 883, 888-89 (193I).

${ }^{\text {as }}$ City of Vallejo v. Superior Court, I99 Cal. 498, 249 P. I084 (I926).
} 
disqualification. ${ }^{64}$ This standard as applied to disqualification was most authoritatively blessed in Commonwealth Coatings Corporation v. Continental Casualty Company, ${ }^{65}$ a review of an arbitration case in which the arbitrator had an undisclosed financial dealing with one of the parties. The United States Supreme Court held, particularly in the light of the disclosure provisions of the Rules of the American Arbitration Association, that the arbitrator, though in fact perfectly fair, must "disclose to the parties any dealings that might create an impression of possible bias." Justice Blackmun, interrogated during his confirmation hearings on the "appearance of bias" phrase in Commonwealth Coatings, expressly endorsed the passage and explained that it was why he had, after the opinion, abstained from hearing a case in which he held even a small amount of stock in a party. ${ }^{66}$

The appearance-of-impropriety concept had not, before Commonwealth Coatings, been overtly applied in the Supreme Court. It may be accepted that the principle was often given implicit recognition in the federal courts, for it is well known that, particularly as the number of judges has increased, federal judges have quietly erased themselves from particular situations which they thought awkward. Nonetheless, as noted above, ${ }^{67}$ the articulated view in federal courts is that absent a certain basis for disqualification, a judge was obliged not to remove himself. Edwards v. United States $^{68}$ presents a vivid illustration of the operation of this principle and its reception by a great judge. In Edwards, the case was first decided by three judges, one from another circuit, one who soon after died, and Judge Rives. The Court of Appeals later set the matter for an en banc hearing, and it was heard by seven judges. Judge Rives believed that, since he was the only one of the original panel left, to insure "the appearance of fairness to the appellants," he should not sit. After consulting his fellow judges, who divided, he finally concluded that regardless of appearances, he had to sit, and this regardless of the absence of the others: "While their absence makes me prefer not to sit, I have not found that it furnishes me any legal excuse."

I believe that Commonwealth Coatings conflicts with the spirit of Judge Rives' renunciation of the power to withdraw. The loose and ambiguous standard endorsed by the Supreme Court in Commonwealth Coatings is troublesomely vague as a guide to conduct; it comes close to being an appeal to conformity for conformity's

\footnotetext{
oc ABA Comm. on Professional Ethics, Opinions, No. 200 (1957). I find no subsequent ABA Committee opinion on point. The canon is incidentally and tangentially applied by the New York County Lawyers Association. N.Y. County Lawyers Ass'n on Professional Ethics, Opinion No. 346 (1956).

6E 393 U.S. I45 (1968).

oo Blackmun Hearings 49. Judge Haynsworth also expressly endorsed the "appearances" standard. Haynsworth Hearings 295. A thought similar to Commonwealth Coatings appears in Berger v. United States, 255 U.S. 22, 35-36 (r92I): "The tribunals of this country shall not be impartial . . but shall give assurance that they are impartial ...."

ar See text at note 35 supra.

${ }^{\text {e8 }} 334$ F.2d 360 (5th Cir. 1964).

${ }^{60}$ Id. at 362 n.2.
} 
sake. It is a standard which in the great cases, at least, is subject to the abuse of manipulation. A determined press or opposition could manufacture an appearance of impropriety, as may be currently happening in respect to Justice Douglas on obscenity cases.

On the other hand, the trouble with Judge Haynsworth's trifling holdings in the Grace Lines and Maryland Casualty cases is that they do conflict with the appearance of justice. Senator Griffin stressed the concrete case of the injured seaman who claimed $\$ 30,000$ against Grace Lines and got \$50. He quoted Professor David Mellinkoff of UCLA Law School, who said, "By the standards of the marketplace perhaps Judge Haynsworth's stockholding was trifling. But it looms large in the mind of the unhappy litigant searching to discover just what it was that tipped the scales of justice against him."70 Senators repeatedly adverted to Canon 4 or its principles in voting against the nomination. Of the six dissenters in the Judiciary Committee, three rested very squarely on this ground. ${ }^{71}$

During Reconstruction days, Senator George Boutwell once said of the fourteenth amendment, "The point relating to 'privileges and immunities' came from Mr. Bing. ham of Ohio. Its euphony and indefiniteness of meaning were a charm to him."72 "Appearance of impropriety" has that same charm of euphony and indefiniteness. With its present high sponsorship, the phrase will most likely be in the law of disqualification for as long as has been "privileges and immunities"-but probably not with so little practical effect.

\section{IV}

\section{The Carswell and Blackmun Appointments}

With Judge Haynsworth defeated, President Nixon came back with Judge George Harrold Carswell as his new proposal. Judge Carswell had certainly not sat in cases in which he held stock in a party, for he held none; and he had accepted no fees for outside services. ${ }^{73}$ His only previous significant involvement in stockholding cases had been as one of three judges in the Fifth Circuit who had recently, during the Haynsworth consideration, declared that a judge might sit if he had small stock holdings and who had then, in apparent conflict with the ruling, proceeded to take those judges out of the case. ${ }^{74}$

\footnotetext{
${ }^{70}$ HAYNSWORth RePoRt, supta note 54, at 46. Senator Griffin felt that Judge Haynsworth had also improperly sat in Nationwide Mutual Insurance Company v. Akers, 340 F.2d 150 (4th Cir. 1965) and Toole v. Nationwide Mutual Insurance Company, 353 F.2d 508 (4th Cir. 1965), because he held 500 shares of stock in a company affiliated with Nationwide Mutual Insurance Company.

${ }^{71}$ They were Senators Bayh, Tydings, and Griffin. Haynsworth Report, supra note 54, at 37, 52, 46.

72 G. BOUTWELI, RENINISCENCES OF SIXTY YEARS 4 I (Ig02).

78 "It is simply that in my position, I have not accepted and will not accept any fees for outside services, period." Hearings on the Nomination of George Harrold Carswell to be Associate Justice of the Supreme Court Before the Senate Comm. on the Judiciary, grst Cong., 2d Sess. 43 (1970) [hereinafter cited as Carswell Hearings]. Judge Carswell, as a representative of the Fifth Circuit, had voted for the strict Judicial Conference Resolution of Junie, 1969 , and continued to endorse it.

${ }^{2 t}$ Judge Carswell referred to this case, Austral Oil Company v. Federal Power Commission, No.
} 
Two other disqualification problems received some attention in the Carswell hearings. Senator Kennedy expressed an interest in whether the nominee had heard cases involving former clients. The Judge responded that any such instances would necessarily have been extremely rare, since he had been a United States Attorney and out of the practice for several years before he became a district judge. ${ }^{75}$ Judge Carswell stated that he had applied to himself the appearance-of-impropriety test rather than the substantial interest test, preferring to be stricter with himself than the statute requires. ${ }^{76}$ Even so, Judge Carswell had a minor uncomfortable moment with what had been a plain lapse of memory or error of judgment. When the Judge was United States Attorney, a liquor violation was tried by his office against a man named Adams. Later, Judge Carswell sat as a district judge in a collateral attack upon a perjury judgment involving testimony given by Adams in the liquor case. On appeal, the issue of disqualification was presented to the Court of Appeals. Two judges found no impropriety, accepting Judge Carswell's statement that while the prosecution had occurred during his administration, he did not know that the case had been in his office. In addition, they stressed that defense counsel had known of the previous involvement and had made no objection at trial. Judge Brown, dissenting, felt that the dates were so obvious on the record that Judge Carswell should have known of his previous connection, there having been only a five-month gap between the original trial and the perjury indictment. ${ }^{77}$

The only other ethical matter raised in connection with Judge Carswell was whether he had allowed his home to be improperly used by others to lobby a horseracing track bill through the Miami legislature. ${ }^{78}$ Upon analysis, this episode appears to be insignificant, as do the others. In the committee report and the dissent of several Senators, no one rested his opposition on ethical grounds. Judge Carswell's defeat lay in doubts as to his general competence and as to his attitude on contemporary issues of civil rights, and not in any serious questions of conflicts of interest.

To the general relief, the next appointment was Judge Harry Blackmun of the Eighth Circuit Court of Appeals. Judge Blackmun, obviously capable and obviously ethical, was confirmed without difficulty. In the area of conflict of interest, it was not easy to distinguish his from the earlier cases. He had participated in cases involving corporations in which he had small holdings. He documented fully that this was acceptable practice in the Eighth Circuit at the time, but affirmed that times

27492 (5th Cir., filed Oct. I7, r969), as one in which "we disqualified the entire panel." Carswell Hearings 43. He refused to be drawn into any decisive discussion as to his standing on small holdings.

${ }^{75}$ Carswell Hearings 26-34.

${ }^{70} \mathrm{Id}$. at 34 .

${ }^{77}$ Adams v. United States, 302 F.2d 307 (5th Cir. 1962). Judge Brown's dissent raised a plain question of integrity. He said, "T am at a loss to understand how we conclude that Judge Carswell knew nothing of the prior activity-that is, was not aware of the "significance' of what he was doing." Id. at $3 \mathrm{Ir}$.

${ }^{78}$ Carswell Hearings 49. 
had changed. More recently, after the Haynsworth episode, he had disqualified in precisely the kind of small interest case in which he previously would have sat. ${ }^{70}$ He testified that he would interpret "substantial interest" in the statute as meaning any interest at all so far as it applied to him. ${ }^{80}$ There is a further comparison with Judge Haynsworth, who had participated in the disposition of the Brunswick case despite his purchase of stock between the time of decision and the final determination. Judge Blackmun had done the same thing, having acquired stock in the Minnesota Mining and Manufacturing Company between the time of the decision of the case concerning that company and the denial of a petition for rehearing. ${ }^{31}$

The Blackmun episodes are hard to distinguish from the Haynsworth situation. Yet, at least the marginal votes which defeated Judge Haynsworth came from Senators sincerely troubled about conflict of interest. ${ }^{82}$ I anticipate a stricter practice for the future. Judge Haynsworth was, in truth, the victim of the highly ambiguous federal disqualification statute which requires disqualification only in cases of "substantial" interest. ${ }^{83}$ As an aftermath of the affair, Senator Bayh has offered a complete revision of the disqualification statute to bring it up to the standard applied in the Haynsworth case.

\section{$\mathrm{V}$}

Responses to the NeEd for New Law:

The Traynor Committee Report and the Bayh Bill

As an aftermath of the resignation of Justice Fortas from the Supreme Court, the American Bar Association appointed a committee, headed by retired Chief Justice Roger Traynor of California, to review generally the matter of standards of judicial conduct. This included disqualification. Meanwhile Senator Bayh prepared a bill on disqualification and has circulated it among judges, lawyers, and professors for suggestions. ${ }^{84}$

${ }^{79}$ Blackmun Hearings 49 .

${ }^{80}$ Id. at $49-50$.

${ }^{81}$ Minnesota Mining \& Mfg. Co. v. Superior Insulating Tape Co., 284 F.2d 478 (8th Cir. 1960); see Blackmun Hearings 19, 46. Blackmun heard four cases involving corporations in which he held stock: Hanson v. Ford Motor Co., 278 F.2d 586 (8th Cir. r960); Kotula v. Ford Motor Co., 338 F.2d 732 (8th Cir. I964), cert. denied, 380 U.S. 979 (x965); Mahoney v. Northwestern Bell Telephone Co., 377 F.2d 549 (8th Cir. 1967); and Minnesota Mining, stipra. He held fifty shares or less in Ford and fewer than fifty in Northwestern Bell's parent corporation, A.T.\&T. In the Kotula case, Blackmun ruled for Ford; in Hanson, he ruled against Ford. He ruled for Northwestern Bell and against Minnesota Mining. Blackmun Hearings 30, 46-47. The Judiciary Committee was not troubled by the conflict caused by these "minuscule interests." Comattee on the Judiciary, S. Exec. Rep. No. 9r-r8, 91st Cong., 2d Sess. 2 (1970).

${ }^{82}$ Senator Bayh believed that a major distinction between the two nominations lay in the fact that Judge Blackmun had no parallel experience to that of Judge Haynsworth with Vend-A-Matic. Ix 6 Cono. REc. S703I (daily ed. May 12, I970).

${ }^{88} 28$ U.S.C. $\$ 455\left(\mathrm{Ig}_{9}\right)$.

84 The bill was also introduced by Senator Tydings, Chairman of the Subcommittee on Improvement of Judicial Machinery of the Senate Committee on the Judiciary. I worked with Senator Bayh in preparing this bill, which was, in earlier draft form, widely circulated by Senator Bayh to attorneys, professors, and judges for comment. It was then revised in the light of the suggestions received. 
The Traynor Report. ${ }^{85}$ This proposal, as it existed in July, 1970, provided that a judge should disqualify himself in any proceeding in his court in which he knows or should know that he, individually or as a fiduciary, or any member of his family residing in his household, has an interest in the matter in controversy or the affairs of a party to the proceeding. An "interest" for the purpose of this standard includes any legal or equitable interest, no matter how small, in a party or in the res or issue in litigation, or any directorial, advisory, or other active participation in any enterprise involved in the litigation. It includes ownership of shares in a mutual fund or other entity holding a substantial interest in a party to the litigation.

The proposal further provides that disqualification should be by full disclosure of record as to the nature and extent of the judge's interest. When such disclosure indicates that a judge's interest is insubstantial, he may, upon written request by all parties to the proceeding, withdraw his disqualification and participate in the proceeding.

The Bayh Bill. ${ }^{86}$ The bill, as it existed in July, 1970, provided that:

Any justice or judge of the United States shall disqualify himself, and shall not accept waiver of disqualification, (I) in any case in which he has an interest, which shall include any stockholding in a corporate party, any stockholding in a corporation which holds to percent or more of the stock of a corporate party, any stockholding in a corporation of which to percent or more of the stock is held by a corporate party, and the holding of any office of a corporation described in this section; (2) in any case in which he has been of counsel; (3) in any case in which he is so related to or connected with any party or attorney as to create a conflict of interest or otherwise render it improper for him to sit on the trial, appeal, or other proceedings; (5) in any case in which his participation in the case will create an appearance of impropriety; and (6) in any other case in which, in his opinion, it would be improper for him to sit.

The Traynor proposal is a vast step forward from existing federal law, but it would profit from a larger infiltration of the Bayh standards.

I. The Traynor plan still permits waiver of disqualification, and the bill would not. I go with the Senator. Waiver is acceptable when the lawyers need not regularly appear before the same judges. For example, it has been sensibly approved as to arbitration, where the attorneys may never again appear before the arbiter. ${ }^{87}$ In the conventional hometown courthouse situation, however, waiver is simply a device for bludgeoning counsel who will have to appear before the judge again and again. It reduces disqualification to a form. According to legend, Judge Learned Hand held twenty-five shares of Westinghouse, of which he advised counsel in cases involving that company; they waived the interest to keep Judge Hand..$^{88}$ If one may throw a small dart at the memory of the departed great, it would have been better if Judge

\footnotetext{
${ }^{85}$ Interim Report of the Special Committee on Standards of Judicial Conduct (mimeo. June 1970).

${ }^{80}$ The Senator's proposals are set out in their entirety in the Appendix.

${ }^{87}$ See Commonwealth Coatings Corp. v. Continental Cas. Co., 393 U.S. I45 (1968).

${ }^{88}$ See Testimony of Judge Lawrence Walsh, Haynsworth Hearings $x 54$.
} 
Hand had not so warmly cherished his tiny stake in the corporate system and had sold those shares. The statement of Judge Biggs, quoted earlier, of universal waiver in the Third Circuit proves too much. Had Judge Haynsworth not shared this view of small holdings, I suspect he would be a Supreme Court Justice today. In his testimony he said of small holdings that "the judges we have are simply not affected by such things." ${ }^{89}$ This, if I may be forgiven, is judical establishment complacence. Others do not find it so difficult to think ill of fellow men in high places.

In taking this position against waiver, I do not overlook the awkwardness of disqualification. If Judge $A$ goes out, a Judge $B$ must come in, and from somewhere. The attendant inconvenience is tolerable, however. Today, with an enlarged federal judiciary, only a few states have but one judge, and in those states, the volume of federal litigation is, of course, small or there would be more judges. It may be accepted that those few judges will be compelled to limit their stock holding as an inescapable burden of office. If the non-waiver standard were adopted by the Traynor Committee and the American Bar Association, it would apply as well to the states. Since these judicial systems commonly have more judges available, any disruption should be minimal.

In short, I have no doubt, upon the basis of extensive communications, that the bar regards any waiver system as a velvet blackjack..$^{00}$

2. The Traynor plan covers any holding in a party, regardless of size. This is as it should be, and the Fifth Circuit and other isolated exceptions should be abandoned. The Traynor plan includes interests in holding companies in general; the Bayh bill gives a concrete measure as to their size, which is appropriate to legislation but not to a general standard. The Senate bill also covers holdings in subsidiaries of a party which, in view of the economic interdependence, is desirable, and this the Traynor report might also well do.

3. The bill, like existing law and canons, covers disqualification because of family relationship, or connection as counsel, or as a material witness. The Traynor draft would profitably include these elements as well.

4. The major difference between the Traynor draft and the Bayh measure is in the proposed statutory provisions for disqualification "in any case in which his participation in the case will create an appearance of impropriety," or "in any other case in which, in his opinion, it would be improper for him to sit." The developing law on this standard, discussed in the preceding sections of this essay, imperatively must be included in the standards. If nothing else, Commonwealth Coatings requires it.

The earlier discussion refers to the doubts of Judge Rives in the Edwards case, and his conclusion that he must sit, despite the appearance which troubled him.

\footnotetext{
${ }^{80}$ Id. at 296.

${ }^{80}$ As Senator Bayh suggested in his statement upon the introduction of his bill, "Such waivers are often made because counsel dare not jeopardize their relationship with the judge before whom they appear regularly by seeming to question his impartiality."
} 
The object of these two subdivisions of the Bayh bill is to give Judge Rives and others like him the latitude he felt he lacked. These sections free the judge from the rigid fetters of hard-line rules and let him take into account his sense of appearances as well as his subjective sense of what is right. They wipe out the "duty to sit" rule as an absolute mandate. As has been said, the standards of the Bayh bill are those in fact being applied by the Supreme Court and by the Senate. If this is the law the Court and the Senate intend to apply when passing judgments, then it should be statutory.

Returning to the responses to my 1947 inquiry, the senior judge of the Seventh Circuit, Judge Evan A. Evans, stated, "Our understanding is that each judge must for himself decide whether [he] is conscious of a feeling or a leaning which would make it unfair to his ideals and to the litigants for him to sit." The Chief Justice of Nebraska responded, "Essentially the questions you ask are questions which each judge decides for himself." The Chief Judge of the New York Court of Appeals reported, "In so far as any relationship or interest outside statutory prohibition is concerned, the practice of this Court is for the individual Judge to decide the question." The function of the Bayh provisions is not to dictate how the judge shall use his judgment, but to give him the power to exercise it.

\section{VI}

\section{Peremptory Challenge to the Trial Judge}

The Traynor report and the Bayh bill overlap on the right or duty of the judge to disqualify himself. However, the bill moves into an area wholly outside the scope of interest of the Traynor Committee when it reaches disqualification of trial judges at the instance of a party.

The existing federal statute permits a party to disqualify a judge for bias and prejudice. What is required is actual bias and prejudice. ${ }^{91}$ The affidavit of disqualification is tested by the trial judge to determine whether a complaint states a cause of action. ${ }^{92}$ The statute is strictly construed, ${ }^{93}$ and some district judges take extreme umbrage when an affidavit is filed.

Many states permit disqualification essentially at the option of a party and leave the disqualified judge nothing to determine except whether the application is timely made. The Bayh bill adopts this liberal disqualification practice by eliminating from existing law any requirement that the party state the facts or the reason for believing that bias or prejudice exist. The affidavit is thus reduced to a form of words; the disqualification becomes the same as a peremptory challenge to a juror, and is simply

\footnotetext{
${ }^{01} 28$ U.S.C. $\$ 144$ ( 1964$)$.

${ }^{02}$ See, e.g., Tynan v. United States, 376 F.2d 76r (D.C. Cir.), cert. denied, 389 U.S. 845 (1967); Rosen v. Sugarman, 357 F.2d 794 (2d Cir. 1966).

${ }^{03}$ Skirvin v. Mesta, I4I F.2d 668 (roth Cir. 1944) is typical of this report.
} 
an expression that the party prefers another judge. The system is thus regarded in states which follow it. ${ }^{94}$

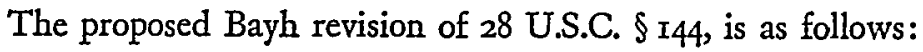

Whenever a party to any proceeding in a district court makes and files a timely affidavit that the judge before whom the matter is pending has a personal bias or prejudice either against him or in favor of any adverse party, such judge shall proceed no further therein, but another judge shall be assigned to hear such proceeding. The affidavit shall be timely if filed (a) twenty or more days before the time first set for trial or (b) within ten days after the filing party is first given notice of the identity of the trial judge or (c) when good cause is shown for failure to file the affidavit within such times. A party may file only one such affidavit in any case, and only one affidavit may be filed on a side. A party waives his right to file an affidavit by participating in a hearing or submission of any motion or other matter requiring the judge to exercise discretion as to any aspect of the case or by beginning trial proceedings before the judge.

It will be noted that either side of a case has one opportunity, without limitation, to ask for a different judge. ${ }^{95}$ The restriction of one such request to a side does not overlook the fact that there may be conflicting or independent interests on a "side." Rather, the proposal rejects this consideration because the goal is substantial justice within the limits of available judicial personnel and one challenge per side is as many strikes as the structure can carry. There are, of course, cases in which various parties formally aligned on the same side are truly adversary to each other. California, which uses essentially this system, has seen fit to regard each adversary interest as a "side," giving each a possible strike. ${ }^{98}$ But there" are not enough federal judges for such a luxury, and after the peremptory challenge has been used, there remains in any case the complete and independent protection of section 455, with its six grounds of disqualification still operative. Thus, for example, if Judge $A$ is removed by defendant's affidavit under section I44, and Judge $B$, plaintiff's cousin, replaces him, the defendant cannot remove Judge $B$ by affidavit but Judge $B$ would commit reversible error under section 455 if he did not remove himself voluntarily.

Disqualification must not be a gimmick for delay. Hence, the proposed revision requires that disqualification be exercised before the eve of trial. On the other hand, most cases are settled. To avoid promiscuous and needless disqualification, the affidavit should not be required much before trial. The bill is designed to suit both

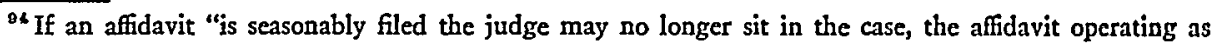
a peremptory challenge to the judge." Conkling v. Crosby, 29 Ariz. 60, 68, 239 P. 506, 509 (I925).

${ }^{95}$ The affidavit form is retained as a gesture of deference to the familiar, and to the fact that some cases seem to regard at least a perfunctory affidavit as constitutionally necessary. See Austin v. Lambert, Ir Cal. 2d 73, 77 P.2d 849 (1938); Daigh v. Schaffer, 23 Cal. App. 2d 449, 73 P.2d 927 (1937). These cases are discounted by limiting language in Johnson v. Superior Court, 50 Cal. 2d 693, 329 P.2d 5 (1958); State v. Sixth Judicial District, 58 Nev. 456, 83 P.2d ro3I (I938); State v. Vandenberg, 203 Ore. 326, 280 P.2d 344 (I955). I do not believe that this form is required, and think that a simple motion would be of equal validity with an affidavit.

${ }^{08}$ The existence of the two sections avoids the problem considered in Johnson v. Superior Court, 50 Cal. 2d 693, 329 P.2d 5 (1958), which deals with the problem of having adverse parties on a side.
} 
the individual and master calendar systems. Where individual calendars are used, the parties know their judge well in advance and must file twenty or more days before the time set for trial. In master calendar systems, parties may not know until very late. Where the assignment is made less than twenty days before trial, the amendment gives the party up to ten days for objection. A "good cause" loophole is left for exceptional cases.

The peremptory disqualification device should also not be a gimmick for waste or maneuver. A party should not be allowed to test the judge, educating him through motions, and then go find someone else because dissatisfied with the rulings. The amendment seeks to limit this possibility.

Predictably, one's response to the disqualification sections of the Bayh bill will reflect the critic's experience under his own state law. The section on the judge's self-disqualification elicits an almost unanimously favorable consensus, as reflected in responses to Senator Bayh's broad-scale inquiry. The response on peremptory disqualification is less uniform. Here, too, one tends to confuse the familiar with the necessary. Those from "hard" disqualification states are shocked to suppose that one can strike a judge as he would a juror. Those from "soft" disqualification states take it as a matter of course.

The proposal is sound, however. The plain truth is that one judge is better than another, and attorneys should be entitled to consider this. Certainly one is better than another for particular cases. If one is too slow to satisfy plaintiffs, or too generous with other people's money to satisfy defendants, or too crotchety to satisfy anyone, why not let litigants take these relevant factors into account? Resistance, I suspect, will be personal and emotional; the judge does not like to be judged. $\mathrm{He}$ may be comforted by the fact that the system works without strain or humiliation where it exists.

There will be problems; the matter of a few states with only one judge has been mentioned. But the problems are small in relation to the whole volume of law business, the overwhelming bulk of which is in districts in which cases can be perfectly readily shifted from one judge to another and in which it is often a matter of chance where they fall in the first instance.

The Bayh bill on disqualification would substantially improve federal justice, and much of it can be incorporated into the Traynor Committee standards. Its innovations are modest, well-rooted in existing $A B A$ standards and state practice. If one may paraphrase Justice Cardozo on another theme, there is proposed no seismic innovation. The edifice of justice would stand, its symmetry greater than before. 


\author{
A P P E N D I X \\ JUDICIAL DISQUALIFICATION ACT OF 1970 \\ as introduced by \\ SENATOR BAYH AND SENATOR TYDINGS
}

Be it enacted by the Senate and House of Representatives of the United States of America in Congress assembled, That this Act may be cited as the "Judicial Disqualification Act of 1970."

Sec. 2. Section 455 of title 28 , United States Code, is amended to read as follows:

" $\$ 455$. Interest of justice or judge

"Any justice or judge of the United States shall disqualify himself, and shall not accept waiver of disqualification, (I) in any case in which he has an interest, which shall include any stockholding in a corporate party, any stockholding in a corporation which holds so percent or more of the stock of a corporate party, any stockholding in a corporation of which ro percent or more of the stock is held by a corporate party, and the holding of any office of a corporation described in this section; (2) in any case in which he has been of counsel; (3) in any case in which he is or has been a material witness; (4) in any case in which he is so related to or connected with any party or attorncy as to create a conflict of interest or otherwise render it improper for him to sit on the trial, appeal, or other proceedings; (5) in any case in which his participation in the case will create an appearance of impropriety; and (6) in any other case in which, in his opinion, it would be improper for him to sit."

Sec. 3. Section $\mathrm{I}_{44}$ of title 28 , United States Code, is amended to read as follows:

"§ I 44 . Bias or prejudice of judge

"Whenever a party to any proceeding in a district court makes and files a timely affidavit that the judge before whom the matter is pending has a personal bias or prejudice either against him or in favor of any adverse party, such judge shall proceed no further therein, but another judge shall be assigned to hear such proceeding. The affidavit shall be timely if filed (a) twenty or more days before the time first set for trial or (b) within ten days after the filing party is first given' notice of the identity of the trial judge or (c) when good cause is shown for failure to file the affidavit within such times. A party may file only one such affidavit in any case, and only one affidavit may be filed on a sidc. A party waives his right to file an affidavit by participating in a hearing or submission of any motion or other matter requiring the judge to exercise discretion as to any aspect of the case or by beginning trial proceedings before the judge." 